\title{
JORGE CARRERA ANDRADE Y LA VANGUARDIA
}

\author{
POR \\ J. ENRIQUE OJEDA \\ Bosion College
}

Nacido en 1902, Jorge Carrera Andrade formó parte de aquella generación literaria del Ecuador en la que el modernismo alcanzó su hora cenital y el posmodernismo obtuvo un amplio desarrollo. Casi contemporáneo de los modernistas ecuatorianos, compuso Carrera Andrade sus primeros ensayos poéticos bajo el influjo de los maestros que habían inspirado a aquéllos: Verlaine, Baudelaire, Rimbaud, Samain. Sin embargo, condiciones espirituales diferentes le llevaron, como a otros posmodernistas hispanoamericanos, a buscar nuevos estímulos en el hontanar de la poesía francesa que sucedió al simbolismo.

En un principio le sedujo la modulación pastoral y elegíaca de Francis Jammes. Más tarde, durante su primer recorrido por Europa (19281933), siguió de cerca el desarrollo de las escuelas que integraron la vanguardia. Su obra antológica y crítica, Poesía francesa contemporánea, iniciada en 1929 y terminada e impresa por la Casa de la Cultura Ecuatoriana, en 1952, revela el amplio y profundo conocimiento que de ella alcanzó Carrera Andrade a lo largo de esos veinte años de asiduos estudios.

No puede dudarse que el vanguardismo, de tan extraordinario y vasto poder sugestivo, fue despertando ecos en la poesía que el escritor ecuatoriano compuso al tiempo que analizaba y traducía las obras de los cultores de las nuevas y atrevidas escuelas estéticas francesas. Las observaciones que siguen tratan de rastrear esos influjos, destacando al mismo tiempo lo original de su postura en lo que concierne a la creación poética, postura que él definió con rara clarividencia y defendió con entereza en análisis que han ido escalonando su quehacer literario. 


\section{EL LEGADO DEL MODERNISMO ECUATORIANO}

El modernismo en el Ecuador cristalizó efímeramente en la obra de cuatro poetas jóvenes: Ernesto Noboa Caamaño (1889-1927), Humberto Fierro (1890-1929), Arturo Borja (1892-1912) y Medardo Angel Silva (1898-1919). A ellos habría que añadir Gonzalo Zaldumbide, uno de los más refinados prosistas del modernismo hispanoamericano, cuya novela inconclusa, Egloga trágica, escrita entre 1910 y 1911, vio la luz en 1916.

Arturo Borja fue el adelantado. Sus poesías empezaron a aparecer en la revista Letras, que, iniciada en 1912, año en que murió Borja, vino a ser la voz del modernismo en el Ecuador. Esta y otras publicaciones del país difundieron la escasa obra de estos poetas, que, al fin, fue recogida en magros volúmenes: El árbol del bien y del mal (1918), de Medardo Angel Silva; El laúd en el valle (1919), de Humberto Fierro; La flauta de ónix (1920), de Arturo Borja, y Romanza de las horas (1922), de Ernesto Noboa Caamaño. Tras estas bruscas reverberaciones, que apenas duraron diez años, se extinguió el modernismo ecuatoriano.

Circunstancias interiores y exteriores intensificaron en esos jóvenes poetas esa inconformidad con su medio, de la que brotaron sus composiciones más conmovedoras. Noboa Caamaño y Borja pertenecían a la rancia nobleza quiteña y habían vivido en París, donde se dejaron seducir por el sortilegio del simbolismo que selló su destino. Humberto Fierro provenía de una familia de clase media adinerada; nunca cruzó las fronteras patrias y, sin embargo, transitó a lo largo y ancho de la cultura universal en virtud de nutridas lecturas. El guayaquileño Medardo Angel Silva, nacido en un medio muy modesto, vivió en un mundo de sueños fastuosos con los que corregía la opacidad de su existencia.

La más desencantada melancolía rezuma la obra de esos poetas. Añoraban ese modo de vida selecto y delicado cuyo derrumbamiento se inició en el Ecuador en 1895 con el triunfo del liberalismo mesocrático. Pero obedecían también a esa consigna esencial del simbolismo por la que había de mantenerse una voluntad de protesta "contra la existencia social moderna y contra una concepción positiva del universo» ${ }^{1}$. Rimbaud había proclamado: "No se vive sino de los sueños y del pasado», y Noboa Caamaño glosó un lema parecido: «Vivir de lo pasado por desprecio al presente / mirar hacia el futuro con un hondo terror.» Nostalgia de la que se hará eco años más tarde Carrera Andrade en los versos iniciales de

${ }^{1}$ Marcel Raymond, De Baudelaire au surréalisme (Paris: José Corti, 1963), p. 49. 
Biogratía para uso de los pájaros ${ }^{2}$ : «Nací en el siglo de la defunción de la rosa / cuando el motor ya había ahuyentado a los ángeles.»

El simbolismo dictó a los jóvenes ecuatorianos lecciones de seriedad. Hasta entonces, escribir versos era considerado en el país un pasatiempo agradable. Mas ahora habíase de seguir a Baudelaire, a quien veían «dividido entre el deseo de elevarse... y de saborear los zumos espesos del pecado... inmoviiizado en el centro de sí mismo, entregado a una especie de horror extático» ${ }^{3}$. Se dedicaron, como él, a cultivar estados de alma excepcionales y buscar en las sustancias alucinógenas un medio de intensificar los procesos creativos. Importaba no transigir con las condiciones normales de la existencia y seguir a Rimbaud, que invitaba a un «largo, inmenso y razonado desorden de todos los sentidos». Sería un error pensar que todos los modernistas ecuatorianos experimentaron con estupefacientes, pues se sabe que Humberto Fierro nunca los usó. Sin embargo, todos se abrazaron a su arte como a un destino cruento. Isaac J. Barrera, mentor y confidente de esos poetas, dijo de ellos que «llevaban el apostolado del arte como una gran cruz impuesta en la mediocridad del ambiente» ${ }^{4}$, y Hugo Alemán se refería a «los tres sacrificados de la poesía» ${ }^{5}$.

Se sabe que el simbolismo trajo consigo complejas teorías sobre los fenómenos de la ensoñación y el sueño, sobre las imágenes y los símbolos, «correspondencias» en las que misteriosamente se reflejaban el universo y el yo. Ya el romanticismo había desconfiado de los procesos lógicos en la gestación poética; los simbolistas, y sobre todo el visionario Rimbaud, los forzaron hasta los limites del ilogismo, desde donde los superrealistas partieron, por el camino de la escritura automática, hacia la noche de la razón, es decir, hacia su negación total. «El vicio llamado superrealista es el empleo desordenado y pasional del estupefaciente imagen», había declarado Louis Aragon en $1927^{\circ}$. Los modernistas ecuatorianos cultivaron poco el lenguaje metafórico, tan esencial al simbolismo. La imagen fue para ellos uno de tantos arbitrios decorativos de la creación poética, no la mirilla a través de la cual podía percibirse esa «tenebrosa y profunda unidad» baudelairiana. Serán los poetas que les sucedieron, y sobre

${ }^{2}$ Jorge Carrera Andrade, Biografía para uso de los pájaros (París: Cuadernos del Hombre Nuevo, 1937); en Obra poética completa (Quito: Casa de la Cultura Ecuatoriana, 1976), p. 251.

${ }^{3}$ Marcel Raymond, op. cit., p. 18.

${ }^{4}$ Isaac J. Barrera, Historia de la literatura ecuatoriana (Quito: Casa de la Cultura Ecuatoriana, 1960), p. 1109.

${ }^{5}$ Hugo Alemán, Presencia del pasado, II (Quito: Casa de la Cultura Ecuatoriana, 1953), p. 185.

${ }^{6}$ Marcel Raymond, op. cit., p. 284. 
todo Carrera Andrade, quienes desarrollarán, en un grado sorprendente, las potencialidades de la metáfora.

Por el contrario, los modernistas ecuatorianos, inspirados por las cadencias y sonoridades de Verlaine, alcanzaron una rara maestría en los aspectos musicales y rítmicos del poema, cumpliendo así otro de los preceptos fundamentales del simbolismo, «el hacer uso reflexivo de los recursos musicales de la lengua» ${ }^{7}$. A Carrera Andrade parecen haberle interesado poco estos elementos del poema. Sus versos fluyen con una gracia natural, pero no revelan una especial dedicación a cultivar efectos sonoros. Su poesía fue siempre eminentemente visual, no auditiva.

Por último, la obra de los modernistas ecuatorianos rezuma un intenso acento elegíaco. Isaac $\}$. Barrera ha demostrado la enorme influencia que ejerció en ella Albert Samain, ese poeta delicado que compuso su obra, en tono menor, en la frontera que separó al simbolismo de las escuelas de vanguardia. Samain murió precisamente en 1900. Su poesía fue un adiós nostálgico al siglo que terminaba, para dar paso a un nuevo mundo de energía y voluntad. También la magra cosecha del modernismo ecuatoriano fue una despedida a una época de tedio y melancolía, a la que iba a seguir otra, afirmativa y esperanzada: la de Carrera Andrade y sus compañeros de labores.

\section{INICIOS DE LA REVOLUCIÓN POÉTICA}

Menor con pocos años a los modernistas ecuatorianos, Carrera Andrade inició sus precoces labores poéticas bajo la estrella del simbolismo. Sus primeros versos, publicados a partir de 1917, parecían presagiar que su poesía estaba destinada a modular las mismas notas elegíacas con que los modernistas habían despedido el siglo.

Pero las circunstancias que presidieron la niñez y juventud de Carrera Andrade fueron muy diferentes. Su familia pertenecía a la clase media; su padre, un distinguido jurisconsulto, estaba afiliado al partido liberal alfarista, tan odiado por los modernistas. La revolución mexicana (1910) y luego la rusa (1917) despertaron en un sector de la juventud ecuatoriana una conciencia social desconocida entre los modernistas y que impulsaba hacia la lucha política. Y en la literatura francesa empezaban a surgir movimientos renovadores de franca oposición al simbolismo. En la revista Letras, que, como se ha dicho, fue el órgano del modernismo ecuatoriano, apareció en 1918 una entrevista a Guillermo Apollinaire en la

\footnotetext{
${ }^{7}$ Ibid., p. 52.
} 
que éste predicaba sin ambages un abierto antibaudelairianismo. «Es preciso reaccionar contra el pesimismo que desde el principio del siglo xIX no ha cesado de visitar a los escritores», declaraba Apollinaire, y proseguía: «Es preciso exaltar al hombre y no disminuirle, deprimirle y desmoralizarle...» (Letras, IV, julio y agosto de 1917, p. 381). También Maurice Le Blond, en su «Essai sur le naturism» (1896), exclamaba: «iBasta! ¡Hace demasiado tiempo que se admira a Baudelaire y Mallarmé! Queremos rejuvenecer nuestro individuo en el abrazo universal. Volvemos a la naturaleza. Buscamos la emoción sana y divina» ${ }^{8}$.

No es probable que Carrera Andrade conociera, por entonces, el ensayo de Le Blond, pero ciertamente leyó a André Gide, cuyos Alimentos terresires (1897) expresaban un nuevo ardor vital y un arrobamiento en el goce sensual de las cosas. "Cualquier conocimiento que no viene precedido por una sensación no me sirve»; «que toda emoción se torne en ti embriaguez», había proclamado Gide, y Carrera Andrade encabezó su primer libro de versos, El estanque inefable (1922), con esta y alguna otra cita de Gide.

Pero fue la yoz patriarcal y campesina de Francis Jammes, su aura de inocencia y mansedumbre y la fresca sensorialidad con que este poeta naturalista exaltaba lo cotidiano, las que impulsaron a Carrera Andrade a dar de mano «la poesía del alma» de los simbolistas y volver la atención hacia la naturaleza y hacia las cosas a las que se sintió ligado por un espíritu de jubilosa fraternidad. Su poema «Del ángelus del alba al ángelus del crepúsculo», publicado en la revista La idea (marzo de 1919, p. 305), capta admirablemente el espíritu y estilo del solitario de Orthez.

Hay que situar en 1918 el primer contacto de Carrera Andrade con la obra de este poeta a través de la Antología de la poesía francesa, publicada por Fernando Fortún y Enrique Díez-Canedo en 1913. Este último había también dado a la estampa en 1920 la traducción de la obra más conocida de Jammes, Del toque del alba al toque de oración. El influjo de este poeta francés fue muy considerable en Hispanoamérica y es posible que Carrera Andrade sintiera su atracción a través de Abraham Valdelomar, cuyos poemas, claramente inspirados en Jammes, aparecían con cierta regularidad en las revistas ecuatorianas de la época.

Sin embargo, las sombras tutelares de la primera hora no fueron apareciendo en un orden cronológico. Refiriéndose a las lecturas que acompañaron sus tanteos poéticos iniciales, Carrera Andrade reveló, en carta al editor de Books Abroad, su temprano eclecticismo: «En poesía, me atraían los simbolistas franceses, un libro no muy conocido de Hugo,

${ }^{8}$ Ibid., p. 67. 
Canciones de las calles y de los bosques, y mi venerado padre Francis Jammes. Después de varios años de vivir bajo la influencia de este poeta, :sentí la garra de Baudelaire» (carta a Roy Temple House del 14 de noviembre de 1940). El impacto de las Flores del mal fue tan profundo que dictó al ecuatoriano todo un volumen de poemas cuyos temas, atmósfera y expresión fueron baudelairianos. Durante su estancia en Berlín, a finales de 1928, Carrera Andrade revisaba esos poemas con miras a la publicación. Su título, Los frutos prohibidos, «atraían a las avispas de la sensualidad por haber madurado al influjo del perfume capitoso de las Flores del mal», según observó él mismo en su autobiografía ${ }^{9}$. Infortunadamente, de esta colección nos queda sólo un poema, "Mademoiselle Satán", cuyo erotismo y referencias, lindantes en lo blasfemo, escandalizó a la Quito conventual de los años veinte, cuando apareció en una revista de esa ciudad sin que lo supiera su autor. Los manuscritos de las restantes composiciones se perdieron en Alemania y Carrera Andrade no quiso reconstruirlos. La obra lírica en que se ocupaba en los años de su primera residencia europea respondía a muy diverso espíritu y a nuevos influjos, que no eran otros que los de las escuelas de vanguardia.

\section{El vanguardismo llega al Ecuador}

En julio de 1922 vio la luz Estanque inefable, primer libro de versos de Carrera Andrade. Los veintisiete poemas que en él se recogen manifiestan ya una parcial ruptura con el modernismo, porque si bien hay todavía composiciones teñidas de la melancolía finisecular que caracterizó a ese movimiento en el Ecuador y alguno que otro tanteo en el estilo de Verlaine, está presente el espíritu del postsimbolista Francis Jammes, admirablemente adaptado a la «provincia» que era el Ecuador de entonces.

El mismo año de 1922 Carrera Andrade y demás jóvenes literatos que integraban el grupo postmodernista en Quito vinieron a un conocimiento más directo de las nuevas escuelas literarias surgidas en Europa al finalizar la Primera Guerra Mundial. El escritor y diplomático César E. Arroyo (1890-1937) había retornado al Ecuador desde España, donde formó parte de aquel equipo que, capitaneado por Rafael Cansinos-Assens, lanzó al mundo hispanohablante el ultraísmo. Cuando en enero de 1919 CansinosAssens pasó a dirigir la revista Cervantes, tornándola ultraísta, Arroyo fue encargado de la sección americana, y en el número de agosto de 1919

9 Jorge Carrera Andrade, El volcán y el colibrí. Autobiografía (Puebla, México: Editorial Cajica, 1970), p. 63. 
apareció una colaboración suya, «La nueva poesía en América, la evolución de un gran poeta», en la que al estudiar la obra del mexicano José Juan Tablada explicaba y defendía el ultraísmo ${ }^{10}$.

Según Cansinos-Assens, el ultraísmo era un «movimiento en el que cabían todas las tendencias y modalidades, con tal que sean nuevas...». Fue Vicente Huidobro quien liberó a Cansinos-Assens y colaboradores de un modernismo encanijado, impulsándoles hacia los nuevos horizontes de la vanguardia ${ }^{11}$.

El diario trato con Arroyo, y sobre todo sus vastas lecturas, familiarizaron a Carrera Andrade con las nuevas escuelas literarias que en esos días parecían multiplicarse inconteniblemente en Europa. Durante su primera estancia en París (1929) se ocupaba en dar toque final a una obrilla de crítica literaria que debía titularse El vanguardismo, con la cual esperaba dar a conocer en Francia las novedades de la creación poética en la América española ${ }^{12}$. Ese estudio no vio la luz entonces, pero algunos de sus conceptos hallaron expresión en una serie de conferencias que Carrera Andrade dictó en las universidades del estado de Nueva York (Stony Brook), Vassar y Harvard entre 1970 y 1971. El volumen que las recoge, Reflexions on Spanish American Poetry ${ }^{13}$, analiza las influencias de la literatura francesa moderna en Hispanoamérica y los postulados que Huidobro y los ultraístas lanzaron en el horizonte de las letras hispánicas. Empieza por sintetizar las escuelas poéticas que aparecieron en Francia a principios del siglo $\mathrm{xx}$ :

Los poetas neosimbolistas siguieron caminos diferentes: hacia el descubrimiento del mundo de las gentes humildes y sus tareas cotidianas con Francis Jammes; hacia el símbolo más elaborado y la arquitectura verbal más perfecta con Paul Valéry; hacia una interpretación de la nueva sensibilidad que fue vibrante y variada con Guillaume Apollinaire. Aparecieron el cubismo pictórico y literario, el futurismo, el. dadaísmo y otras escuelas.

\section{Y luego se refiere a Hispanoamérica:}

En Hispanoamérica la reacción antimodernista tomó varias formas bajo el nombre común de vanguardismo. El creacionismo hace su apa-

${ }^{10}$ Gloria Videla, El ultraísmo (Madrid: Gredos, 1963), p. 87.

${ }^{11}$ Rafael Cansinos-Assens, La novela de un literato (Madrid: Espasa Calpe, 1982), tomo 2 , p. 235.

${ }^{12}$ El volcán y el colibri, op. cit., p. 71.

${ }^{13}$ Reflexions on Spanish American Poetry (Albany, State of New York University" Press, 1973). 
rición con el chileno Vicente Huidobro y el francés Pierre Reverdy, que juntos editan en París la revista Nord-Sud, pero cuya filiación cubista es innegable, lo cual puede igualmente decirse del ultraísmo que nació en Madrid en 1918 después de que Huidobro pasó por esa ciudad. El movimiento ultraísta alcanzó su expresión más plena con las publicaciones Ultra y Cervantes, las cuales llevaron la semilla a América ${ }^{14}$.

Ahora bien, Huidobro, en su conferencia en el Ateneo de Madrid (1921) y en su obra poética, abre un nuevo camino a la poesía hispánica, que va a conducirla al surrealismo:

E1 fuego novedoso de la poesía de Vicente Huidobro consume los últimos restos del modernismo y del ruralismo hispanoamericano. Contribuyen a esta acción los ecos del superrealismo que empiezan a llegar a las playas acogedoras. Se dibujan en el horizonte los dos rumbos fundamentales, opuestos entre sí, señalados por Valéry, que concebía el poema como «una fiesta del intelecto», y por André Breton, que aconsejaba: «La poesía debe de ser la derrota del intelecto.» Es decir, que la oposición era entre la luz y el mundo crepuscular de la subconsciencia. Huidobro intentó fusionar las dos corrientes. Al final abandonó la forma caligramática y la descentralización del poema en versos dispersos, para dar paso a una escritura más fluida, fruto de la imaginación, pero también de una conciencia vigilante ${ }^{15}$.

¿Qué influjo pudo ejercer en la creación poética de Carrera Andrade en esos años la seducción del creacionismo y el ultraísmo? Jorge Luis Borges había formulado en 1921 los postulados ultraístas, insistiendo, entre otros, en la esencial importancia de la metáfora, en la composición de las imágenes como medios de intensificar su poder sugestivo, en la simplificación y concentración del estilo ${ }^{16}$. A lo cual Guillermo de Torre añadió que en el ultraísmo «los aspectos de la naturaleza aparecían metamorfoseados, trocando sus elementos y atribuciones, con el deseo de dar una visión fresca del mundo matinal» ${ }^{17}$.

Una consideración menos atenta de la obra de Carrera Andrade podría hacernos pensar que éste se inspiró en el uiltraísmo para dar a la me-

${ }^{14}$ Reflexions on Spanish American Poetry, op. cit., p. 45.

${ }_{15}$ Ibid., pp. 45-46.

15 Jorge Luis Borges, «Ultraísmo», revista Nosotros (Buenos Aires), núm. 151, diciembre de 1921, p. 466 et al.

${ }_{17}$ Guillermo de Torre, Historia de las literaturas de vanguardia (Madrid: Ediciones Guadarrama, 1965), p. 545; Ramón Gómez de la Serna, Greguerías, 4. ${ }^{a}$ ed. (Madrid: Espasa Calpe, 1945); J. Enrique Ojeda, Jorge Carrera Andrade. Introducción al estudio de su vida y de su obra (Madrid: Tecnos, 1972). 
táfora tan primordial importancia y para revestir su universo poético de ingenuidad y de frescura. Tal es la conclusión a la que parece llegar Gui1 lermo de Torre cuando afirma que «de parejo espíritu [ultraísta] se beneficiaron más adelante poetas como Jorge Carrera de Andrade y Gonzalo Escudero» ${ }^{18}$.

Sin embargo, un análisis más cuidadoso de las primeras composiciones, y sobre todo de las incluidas en Estanque inefable (1922), revelan una inclinación natural -y anterior a todo influjo extrínseco- a contemplar el universo a través de la mirilla de la imagen. Lo mismo debe decirse de su entusiasmo vital, mezcla de cristianismo y de animismo indígena. «La órbita de mi poesía -declaró en una conferencia en Columbia University (1960)_- pudo ir ampliándose merced al instrumento analógico, al instrumento de la imagen» ${ }^{19}$. Y entonces también afirmó: «Mi mundo giraba alrededor de un eje: el amor a las cosas por sí mismas, no por sus reflejos o ecos que despertaban en nuestro intelecto» ${ }^{20}$.

Sería ingenuo negar que el ultraísmo y las otras escuelas de vanguardia dejaran huellas en la poesía de Carrera Andrade. Lo que sí debe sostenerse es que, en medio de esa red de atracciones y repudios que ejercieron sobre él el sinnúmero de programas literarios de esa hora, se mantuvo fiel a su postura espiritual y estética. «Soy un hombre del Ecuador, que ha tratado de conocer el mundo para desenvolver en él su vida como un viaje», declaró en Columbia University, ligando así íntimamente su destino de poeta a su lugar de origen ${ }^{21}$.

Esta fidelidad a los principios espirituales y estéticos que le dictaron su ser de americano, y aún más, de andino, aparecerá más patente al referirnos a esas composiciones originales que su autor distinguió con el nombre de «microgramas».

\section{LA GREGUERÍA Y EL MICROGRAMA}

Guillermo de Torre ha enumerado los arbitrios mediante los cuales los vanguardistas pretendían, a partir de 1920 , decantar la poesía hasta dejarla en su más pura esencia: supresión de lo anecdótico, reducción de lo ornamental en favor de la metáfora, sinestesia, desaparición de la rima, uso del ritmo unipersonal (versolibrismo), supresión de enganches sintácticos,

${ }^{18}$ Guillermo de Torre, Historia, op. cit., pp. 593-594.

19 Jorge Carrera Andrade, Mi vida en poemas (Caracas: Ediciones Casa del Escritor, 1962), p. 39.

${ }^{20}$ Ibid., p. 12.

${ }^{21}$ Ibíd., p. 9. 
prescindencia de cualidades auditivas e insistencia en el valor visual, «en un relieve plástico, una arquitectura visible, que entre por los ojos» ${ }^{22}$.

El segundo libro de versos de Carrera Andrade, La guirnalda del silencio (1926), parece responder en buena medida a este programa, si bien no es probable ni aun posible que el poeta ecuatoriano hubiera leído, en los días en que componía esa obra, las páginas que Guillermo de Torre publicó en Madrid en 1925 con el título de Literatura de vanguardia. Una vez más, se trata de aquella inclinación natural que impulsaba a Carrera Andrade por el camino de la modernidad mediante la práctica de los arbitrios anteriormente señalados, particularmente el uso de la metáfora. En efecto, en La guirnalda del silencio se observa esa tendencia a definir objetos y seres por medio de metáforas, creando breves fórmulas de máxima concreción visual. De esa obra entresacamos algunos ejemplos: «El pájaro es el periódico / de la mañana en el campo» (La guirnalda, p. 19); «y es una red oscura puesta a secar la noche» (ibíd., p. 41); «los mástiles son cañas para pescar estrellas» (ibíd., p. 41); «un libro es tuna casa con ventanas al campo» (ibid., p. 33).

Versos de tan plástico encanto llevaron a su autor a componer, como unidades independientes, una serie de miniaturas líricas a las que, como se ha dicho, puso el nombre de microgramas. Doce aparecieron en Boletines de mar y tierra (1930), once en el Rol de la manzana (1935) y todos éstos, más ocho inéditos, fueron al fin recogidos en un breve volumen, Microgramas (1940). En él constaba un estudio en el que su autor definía este nuevo tipo de poema y se empeñaba en defender su originalidad frente a los epigramas tradicionales, los haiku japoneses y sobre todo las greguerías de Ramón Gómez de la Serna. En mi estudio Jorge Carrera Andrade. Introducción al estudio de su vida y de su obra expliqué con algún detenimiento las relaciones del micrograma con sus congéneres anteriormente mencionados. Baste aquí sintetizar lo que allí se dijo a propósito de microgramas y greguerías.

Según Guillermo de Torre, Gómez de la Serna estuvo sólo tangencialmente relacionado con el vanguardismo, $y$, sin embargo, afirma que «el inventor de la greguería puede vindicar en todo momento, con más motivos que ningún otro de su edad, una indiscutible prioridad vanguardista» ${ }^{23}$. Es curioso que Carrera Andrade no mencionara jamás a Gómez de la Serna entre los autores que influyeron en su obra. Las greguerías habían ingresado en el mundo de las letras en 1910 (revista Prometeo y epílogo a Tapices). La primera antología apareció en 1916 y tuvo numerosas

${ }^{22}$ Guillermo de Torre, Historia, op. cit., p. 540.

${ }^{23}$ Ibíd., p. 524. 
ediciones y refundiciones. Es así muy probable que Carrera Andrade, lector infatigable desde su niñez, conociera tempranamente esas originales creaciones de Gómez de la Serna. De todos modos, hay entre estas singulares obras del español y del ecuatoriano interesantes analogías. Ellas tienen en común: a) Su interés definitorio: «La greguería es el atrevimiento a definir lo indefinible» (Gómez de la Serna, Greguerías, p. 13). Y Carrera Andrade aclara: «Sin embargo, yo no me engañaba acerca de la futilidad de semejante intento de definir las cosas por medio de equivalencias encontradas en el mundo material» (Mi vida, p. 12). b) El uso de la metáfora como método definitorio: «Entre los tropos, la metáfora es lo esencial» (Greguerías, p. 13). Carrera Andrade piensa lo mismo, según se desprende de la cita anterior. c) La atención concentrada en los objetos más insignificantes: «Chesterton ha dicho: el telescopio empequeñece el universo. Es el microscopio el que lo agranda. Esto justifica la labor del observador de lo ínfimo y de lo instantáneo» (Greguerias, p. 27). «Al esquema jocoso de personajes y sucesos [del epigrama] había que sumar el apunte rápido en que se aprisionara el gesto de las vidas insignificantes, despreciadas por los contempladores de un mundo monumental. Así nació el micrograma» (Microgramas, p. 2).

Esta comunidad de elementos parece indicar que tanto Gómez de la Serna como Carrera Andrade estaban empeñados en idéntica labor creadora. Sin embargo, la impresión que la lectura de esas dos obras nos deja es fundamentalmente distinta. Las greguerías están escritas en prosa y responden a un propósito "prosaico», pues su autor declaraba que prefería no darles un aire poético (Greguerias, p. 16). Domina en ellas el humorismo y el deseo de «sorprender», tan caros al pintoresco don Ramón. Hay que recordar la definición de greguería que él formuló: «Humorismo más metáfora, igual a greguería» ${ }^{24}$. Por el contrario, Carrera Andrade inventa sus microgramas con una intención esencialmente lírica, a pesar de que reconoce que se trata de un proceso lógico: «Debo confesar que jamás había experimentado mayor embriaguez intelectual que en este trabajo de reducción de lo creado en pequeñas fórmulas poéticas, exactas, mediante la concentración de elementos característicos del objeto entrevisto o iluminado súbitamente por el reflector de la conciencia» ${ }^{25}$.

Carrera Andrade exalta la trascendencia y la modernidad del micrograma. No obstante su esencial brevedad y aparente insignificancia, éste constituye una antena a través de la cual se puede captar «la realidad profunda del objeto — de su actitud secreta— $\longrightarrow$ y convertirla en «una estiliza-

\footnotetext{
${ }^{24}$ Ibid., p. 526.

${ }^{25}$ Jorge Carrera Andrade, Mi vida..., op. cit., p. 14.
} 
ción poética» (Micrograma, p. 2). E1 humorismo, elemento definidor del epigrama español y de la greguería, es relegado a segundo término. Tiene Carrera Andrade una clara conciencia de la innovación que sus poemas sintéticos implican, cuando afirma: «Era menester añadir al humorismo el sentido trascendental, la vibración de la vida, la grandiosidad del mensaje de las cosas pequeñas.» $\mathrm{Y}$ añade: "Al esquema jocoso de personajes y sucesos había que sumar el apunte rápido en que se aprisionara el gesto de las vidas insignificantes, despreciadas por los contempladores de un mundo monumental» (ibíd.).

De ahí la modernidad de esas miniaturas líricas, cuyo desarrollo futtiro no podía sino ser favorecido por las nuevas tendencias poéticas, o sea, por el vanguardismo. «¿Puede señalarse el itinerario del micrograma en el porvenir?», pregunta Carrera Andrade, para responder a continuación: «Seguramente la síntesis, la novedad de imágenes, el internacionalismo y el infantilismo que son las características de la nueva poesía contribuirán a darle vida renovada y sin término» (ibíd., p. 22).

Para concluir estas consideraciones sobre las greguerías y los microgramas conviene volver la atención sobre los elementos más salientes que Guillermo de Torre atribuye a la poesía vanguardista: supresión de lo anecdótico, importancia de la metáfora, versolibrismo, reducción de lo auditivo e insistencia en lo visual, sinestesia. Ahora bien, ino son precisamente estos elementos los que definen el micrograma? Así, una vez más parece Carrera Andrade haber llegado, por sus propios caminos y en sus propios términos, al venero de la poesía de última hora.

\section{Carrera Andrade Y EL superrealismo}

Se sabe que el superrealismo, que, según Tristan Tzara, «nació de las cenizas de Dada», hizo su aparición con el primer «Manifiesto» de André Breton en octubre de 1924. En él se proponía una nueva actitud filosófica y social y una nueva poética basada en el mundo de los sueños y en la «escritura automática»; es decir, en una expresión del todo liberada de la razón. La imagen, o sea, el lenguaje metafórico, constituía el eje de la creación poética: «E1 vicio llamado superrealismo es el empleo desordenado y pasional del estupefaciente de la imagen», había declarado Louis Aragon ${ }^{26}$. Mas su propósito no era ya más iluminar analogías, sino relacionar elementos antitéticos en arbitrarias asociaciones. Pierre Reverdy había declarado en 1918: "la imagen es una creación pura del espíritu», pero cuidó de añadir: «si los sentidos aprueban totalmente la imagen, la

${ }^{26}$ Cfr. M. Raymond, De Baudelaire au surréalisme, op. cit., p. 284. 
matan en el espíritu». "Hay que desensibilizar el universo», proclamaba otro superrealista, Paul Eluard. Y el mismo André Breton confesaba: «Para mí, la imagen más vigorosa es la que presenta el mayor grado de arbitrariedad» ${ }^{27}$.

Tan abierta rebelión contra la lógica podía ser considerada como el testimonio de una original postura filosófica y estética. En realidad no era sino un retorno, llevado a sus últimas consecuencias, de esa aspiración que inspiró a los mejores espíritus románticos a trascender el mundo de las apariencias para alcanzar el reino nocturno en el que no existen los contrarios. Pierre Guéguen había definido la imagen en 1929 como «la unidad del espíritu nuevamente encontrada en la multiplicidad de la materia», y había añadido: "la imagen no es otra cosa que una forma mágica del principio de identidad ${ }^{28}$. Rotundamente expresó André Breton el mismo concepto en su segundo «Manifiesto»: «Todo lleva a pensar que existe cierto punto en ei espíritu en el cual la vida y la muerte, lo real y lo imaginario, lo pasado y lo futuro, lo comunicable y lo incomunicable, lo alto y lo bajo dejan de ser percibidos como contradictorios. Ahora bien, en vano se buscaría a la actividad surrealista otro móvil que la esperanza de determinar ese punto» ${ }^{23}$. Puesto que por el caos se trataba de alcanzar una supernaturaleza, no sorprende que esta voluntad de compaginar lo contradictorio llevara a los superrealistas a una cierta aceptación de la mística, particularmente según se la practica en las religiones orientales. Por último, no hay que olvidar los patéticos esfuerzos del superrealismo por justificar su adhesión al izquierdismo radical. En efecto, ¿cómo alcanzar la liberación total del espíritu y, al mismo tiempo, defender la dogmática del realismo socialista?

Carrera Andrade residía en Europa (1928-1933) en los precisos días en que el superrealismo se hallaba en plena gestación. Recuérdese que Nadja, la novela de André Breton, apareció en 1928 y su segundo «Manifiesto» en 1930. El joven poeta ecuatoriano siguió con el más vivo interés el desenvolvimiento de esa escuela, que estaba destinada a ser la más importante y duradera de las que formaron la vanguardia. A esta coincidencia temporal habría que añadir otros contactos. En su Poesía francesa contemporánea, al introducir sus traducciones de poemas de André Breton, Carrera Andrade había trazado un juicio admirativo del fundador del superrealismo: «André Breton ha restaurado la imaginación, la rebeldía y la elocuencia y, en medio de las circunstancias más adversas, ha permanecido fiel a su empresa de liberación espiritual» (p. 329). Desde Estanque

\footnotetext{
${ }^{27}$ Ibíd., pp. 286, 288.

${ }^{28}$ Ibid., p. 286.

29 Ibíd., pp. 292-293.
} 
inefable (1922) Carrera Andrade había concentrado su ejercicio poético en la metáfora, adelantándose al programa formulado por André Breton. A Paul Eluard, otra importante figura del superrealismo, le ligaba el cultivo de «imágenes virginales», una cierta «densidad sensorial», lo mismo que una «ternura humilde por los animales y las cosas pequeñas» ${ }^{30}$. Falto de la fe religiosa, Carrera Andrade profesó, a lo largo de su obra, un cierto animismo, heredado, según él, de los aborígenes andinos y que de alguna manera podía ser parangonado con el impreciso misticismo de los superrealistas. Por último, existía otro punto de contacto: el poeta ecuatoriano había viajado a Europa como representante del Partido Socialista de su país al $\mathrm{V}$ Congreso Internacional Socialista, celebrado en Moscú en 1928. Como Breton y otros superrealistas, unía Carrera Andrade su consagración al quehacer poético con una intensa y activa preocupación social y un ansia de promover la solidaridad humana.

Todo parecía indicar que Carrera Andrade ingresaría en las filas del superrealismo o, cuando menos, sería profundamente influido por él como sucedió con tantos poetas sudamericanos de la época, entre los que se contaban sus compatriotas Hugo Mayo, Gonzalo Escudero, Alfredo Gangotena y otros de menor nombradía. Sin embargo, insalvables diferencias separaban al poeta ecuatoriano de los dogmas superrealistas en lo que concernía al quehacer poético. Refiriéndose a la naturaleza y uso de la metáfora, explicaba así él la diferencia que mediaba con los seguidores de Breton: «Pero, mientras la imagen para los surrealistas (sic) es una creación pura del espíritu, una creación gratuita, para mí es una operación de acercamiento de dos realidades existentes, operación por la que ejerzo libremente mis facultades interpretativas» ${ }^{31}$. Ahora bien, esa «libertad interpretativa» que Carrera Andrade confiesa practicar era del todo contraria a la que predicaban Breton y sus seguidores. Estos aspiraban a entrever ese reino misterioso, esa «superrealidad», por medio de un continuo sondeo en el subconsciente, al que sólo se podía llegar mediante un ilogismo ferozmente cultivado y una arbitrariedad absoluta. Por el contrario, Carrera Andrade anhelaba para su poesía la máxima claridad y transparencia, porque su misión era, según él, la de interpretar poéticamente el mundo que le rodeaba. No una superrealidad indefinida y tal vez indefinible, sino la realidad cotidiana, los seres que pueblan el universo: «Por eso, en el homenaje que me hicieron mis amigos en París afirmé que la poesía es el ejercicio más soberano de la libertad individual y me declaré un modesto cronista del cosmos. O sea, un contemplador alerta de los su-

39 Carrera Andrade, Poesia francesa..., op. cit., pp. 246-247.

${ }^{31}$ Carrera Andrade, Mi vida..., op. cit., p. 40. 
cesos de la naturaleza...» ${ }^{32}$ Importa observar que Carrera Andrade no sólo define así su peculiar destino líterario, sino que afirma que éste es el de todo poeta hispanoamericano: «Es en América hispana en donde la poesía se abreva en la fuente primera de las cosas sin reflejos lógicos ni metafísicos» ${ }^{33}$.

En vano se buscaría a lo largo de la obra poética de Carrera Andrade muestra alguna que contradijera esta su postura tan abiertamente antisuperrealista. Unica excepción son los dos poemas titulados «Zona minada», escritos durante su servicio diplomático en el Japón (1938-1940). Pertenecen al volumen País secreto y difieren del resto de las composiciones en él recogidas por su intensa sensualidad que se expresa en imaginería de clara filiación superrealista. Como en el caso de Pablo Neruda y Octavio Paz, la experiencia de vivir en el extremo Oriente parece haber sacudido, si bien momentáneamente en su caso, las estructuras lógicas de su poesía. Así lo declaró Carrera Andrade años después: «E1 Japón es un verdadero paraíso de lo arbitrario y lo sensacional, un cielo surrealista (sic) que deberían visitar André Breton, Benjamin Peret y Salvador Dalí, para darse cuenta de que sus invenciones son apenas tímidos ensayos al lado de esas obras maestras del disparate humano» ${ }^{34}$.

Sin embargo, el balance que podría ser considerado definitivo del superrealismo y su influjo en la poesía hispanoamericana lo hizo Carrera Andrade en 1971 en su libro Reflexions on Spanish American Poetry. En el ensayo "Trends in Spanish American Poetry (Twenty Century)» explicó el fracaso de esa escuela aludiendo a sus errores capitales: «En el curso de pocos años se vio lo estéril del intento. Nada había cambiado en el espíritu del hombre. Se eliminaron los caracteres fundamentales de la poesía -el tema y su desarrollo lógico- y fueron reemplazados por la incoherencia y la oscuridad.» Refiriéndose al impacto de esa escuela en la poesía hispanoamericana, aduce algunos nombres: Luis Cardoza y Aragón, Miguel Angel Asturias, César Moro, Xavier Abril, y concluye: «Pero esta influencia del surrealismo (sic) puro fue sólo temporal, como lo fue también en Pablo Neruda y Vallejo, ya que todos ellos optaron a la postre por imitar la actitud disidente de Lotis Aragon y seguir el camino de la poesía político-social, o sea, afirmar la supremacía de la dimensiôn histórica sobre la dimensión de la subconsciencia.» Concluye sus observaciones alu.

${ }^{32}$ Ibid., p. 40.

${ }^{33}$ Carrera Andrade, Interpretaciones hispanoamericanas (Quito: Casa de la Cultura Ecuatoriana, 1967), p. 268.

${ }^{34}$ Carrera Andrade, Rostros y climas (Paris: Ediciones de la Maison de l'Amérique Latine, 1940), p. 14; Poesía francesa contemporánea (Quito: Casa de la Cultura Ecuatoriana, 1951). 
diendo al influjo benéfico que esa escuela produjo en su propia obra como en la de otros escritores del continente: «El paso del surrealismo (sic) por el campo de la poesía hispanoamericana fue como una lluvia de verano, pero dejó un saldo positivo: el ejercicio de la imaginación como fuerza suprema» (Reflexions, p. 49).

\section{CONCLUSIÓN}

Las consideraciones que preceden dejan en claro que Carrera Andrade tuvo un profundo y vasto conocimiento del vanguardismo. Esa íntima familiaridad fue lograda merced a su paciente y prolongada labor de antologista, traductor y crítico de la poesía francesa contemporánea, como también a sus lecturas y estudios sobre la poesía española, hispanoamericana, inglesa y estadounidense. Resaltan, asimismo, ciertas semejanzas entre los postulados vanguardistas y la actitud poética de Carrera Andrade. La más importante entre ellas fue el uso del lenguaje metafórico, común denominador de todas las escuelas de vanguardia y ciertamente característica dominante en la obra del poeta ecuatoriano. Entre otras semejanzas habría que citar la tendencia a la visualidad y la importancia concedida al mundo natural. Además, ciertos elementos estilísticos: la concisión, la falta de interés en la rima y otros efectos sonoros, el versolibrismo.

Sin embargo, existieron radicales diferencias entre la actitud poética de Carrera Andrade y la de los vanguardistas. Mientras éstos consideraban a la imagen como un medio de escapar al imperio de la lógica, el poeta ecuatoriano sometió sus ejercicios metafóricos a la más rigurosa disciplina mental. Los superrealistas buscaban entre las brumas del subconsciente un reino misterioso; Carrera Andrade anheló iluminar el universo en que vivimos, lejos de toda preocupación teológica o metafísica. Rechazó las pálidas fosforescencias de la escritura automática y se orientó hacia la luz solar. En cierta medida, la obra entera de Carrera Andrade es una profesión de antivanguardismo, la afirmación de una poética abierta a todos los influjos, pero, en el fondo, profundamente original por ser, según declaración suya, medularmente hispanoamericana. En una entrevista concedida al escritor y crítico ecuatoriano Hernán Rodríguez Castelo en 1976, Carrera Andrade sintetizó así su labor de poeta: «Mi aporte fundamental ha sido convertir al poema en un camino de libertad, enriquecer el verso con imágenes nuevas, limpiar el lenguaje hasta alcanzar su mayor pureza, combatir la oscuridad voluntaria y ficticia, conquistar la transparencia, captar la realidad circundante, exaltar la geografía de la Patria y señalar derroteros al hombre ecuatoriano» (El Tiempo, Quito, 13 de junio de 1976, p. 3). 